msh-mss Mathématiques et sciences humaines

148 | Hiver 1999

Varia

\title{
Removal independence and multi-consensus functions
}

Indépendance par suppression et multi-fonctions de consensus

Mark Dwyer, Fred R. Mc Morris and Robert C. Powers

\section{OpenEdition}

1 Journals

Electronic version

URL: http://journals.openedition.org/msh/2798

DOI: $10.4000 / \mathrm{msh} .2798$

ISSN: 1950-6821

Publisher

Centre d'analyse et de mathématique sociales de l'EHESS

Printed version

Date of publication: 1 December 1999

ISSN: 0987-6936

Electronic reference

Mark Dwyer, Fred R. Mc Morris and Robert C. Powers, « Removal independence and multi-consensus functions », Mathématiques et sciences humaines [Online], 148 | Hiver 1999, Online since 10 February 2006, connection on 23 July 2020. URL : http://journals.openedition.org/msh/2798 ; DOI : https:// doi.org/10.4000/msh.2798

This text was automatically generated on 23 July 2020

(c) École des hautes études en sciences sociales 


\section{Removal independence and multi- consensus functions}

Indépendance par suppression et multi-fonctions de consensus

Mark Dwyer, Fred R. Mc Morris and Robert C. Powers

\section{ABSTRACTS}

This analysis is aimed to study Buffon's contributions towards political arithmetic, considered not from the point of view of the historical and technical constitution of demography but by replacing them in the general proposal which commands Buffon's thought. The task for assign to these works their real meaning allows not only to understand the disparity of the judgements they raised up but to enlighten too some of the difficulties they conceal and to show an evolution, which seems to appear in Buffon's relationship to the mathematisation of social sciences.

Vincke et Bouyssou ont montré que, si une procédure d'agrégation de préordres totaux peut retourner plusieurs solutions, alors elle peut satisfaire tous les axiomes du théorème d'Arrow sans être pour autant dictatoriale. Nous étendons cette approche aux hiérarchies utilisées en classification. Dans ce contexte, on obtient des résultats qui peuvent différer de ceux de Vincke et de Bouyssou. 
INDEX

Subjects: classification - partition, décision (théorie de la), jeux (théorie des), ordres et préordres, préférences (agrégation des)

Mots-clés: consensus, hiérarchies, multi-fonctions de consensus, théorème d'Arrow, théorie de la décision

Keywords: Arrow's theorem, consensus, decision theory, multi-consensus function, hierarchy 